\title{
INFLUENCE OF SUBGRADE SOIL ON PAVEMENT PERFOMANCE: A CASE STUDY OF AGO-IWOYE - ILISHAN ROAD, SOUTHWESTERN NIGERIA
}

\author{
J. O. Fatoba ${ }^{1}$, A. O. Sanni ${ }^{2}$, A. B. Ayantunji \\ ${ }^{1}$ Earth Sciences Department, Olabisi Onabanjo University, Ago-lwoye, Ogun State, Nigeria. \\ ${ }^{2}$ Department of Geosciences, University of Lagos, Akoka, Lagos State, Nigeria \\ *E-mail address: hydrofad@yahoo.com
}

Keywords: Sub-grade soils; Geotechnical properties; Pavement failure; groundwater table

\begin{abstract}
Ago-Iwoye -Ilisan road is the major road that links Abeokuta the state capital of Ogun -state to Ijebu towns. The road has always been experiencing pavement failure, which occurs inform of cracks and potholes. Being the major road, the effect of the failure has negative impact on the soicoeconomic growth of Ijebu -areas. The primary objective of the study was to determine the influence of the geotechnical properties of the sub-grade materials on the pavement performance of AgoIwoye - Ilishan Road. Eleven (11) soil samples were collected at eight (8) different locations with the aid of hand auger and were air-dried before taken to the laboratory for determination of engineering properties. The Liquid limit and the Plastic limits ranged from $13.9-46.2 \%$ and $8.1-$ $32.7 \%$, with the Plasticity index from 10.6 - 15.9\% and Shrinkage limit from $6.2-27.7 \%$ respectively. The soaked CBR values of the subgrade materials is between $67 \%$ and $75 \%$ compared with 30\% minimum specified by FMWH, 1997.

The soils were classified by ASSHTO under the A-6 and A-7 category which shows that the soils are fair to poor as a sub-grade material and USCS classification shows that the soil falls into the SM and SC group.

The comparison of all the results with the Nigeria specification (Federal Ministry of Works and Housing general guidelines) for the sub grade materials along the Ago-Iwoye- Ilisian road show that the materials underlain the pavement do satisfy the Nigeria standard. Therefore, the perennial failure frequently experience along the road route is not significantly influenced by subgrade materials. Hence, influence of other factors such as poor drainage courses, level of groundwater table, variation of geologic materials along the road route and poor construction materials should be thoroughly addressed before embarking on future rehabilitation of the highway.
\end{abstract}

\section{INTRODUCTION}

A pavement section may be generally defined as the structural material placed above a subgrade layer (Woods and Adcox, 2006). The characteristic of the soil bed over which the entire pavement system rests on represents subgrade soils (Mcghee, 2010).

Pavement failures are common features of Nigerian roads. Despite several rehabilitation attempts, the reason for their occurrence seems not to be well understood.

The sub-grade provides a foundation for supporting the pavement structure. As a result, the required pavement thickness and the performance obtained from the pavement during its design life will depend largely upon the strength and uniformity of the sub-grade. Hence, a thorough investigation of the sub-grade should be made so that the design and construction will ensure uniformity of support for the pavement structure and realization of the maximum strength potential from the particular sub-grade soils.

Ago-Iwoye -Ilisan road is the major road that links Abeokuta the state capital of Ogun -state to Ijebu towns. The road has always been experiencing pavement failure, which occurs inform of cracks and potholes (see Plate 1\&2).Being the major road, the effect of the failure has negative impact on the socio-economic growth of Ijebu -areas. The primary objective of the study was to 
determine the influence of the geotechnical properties of the sub-grade materials on the pavement performance of Ago-Iwoye - Ilishan Road.

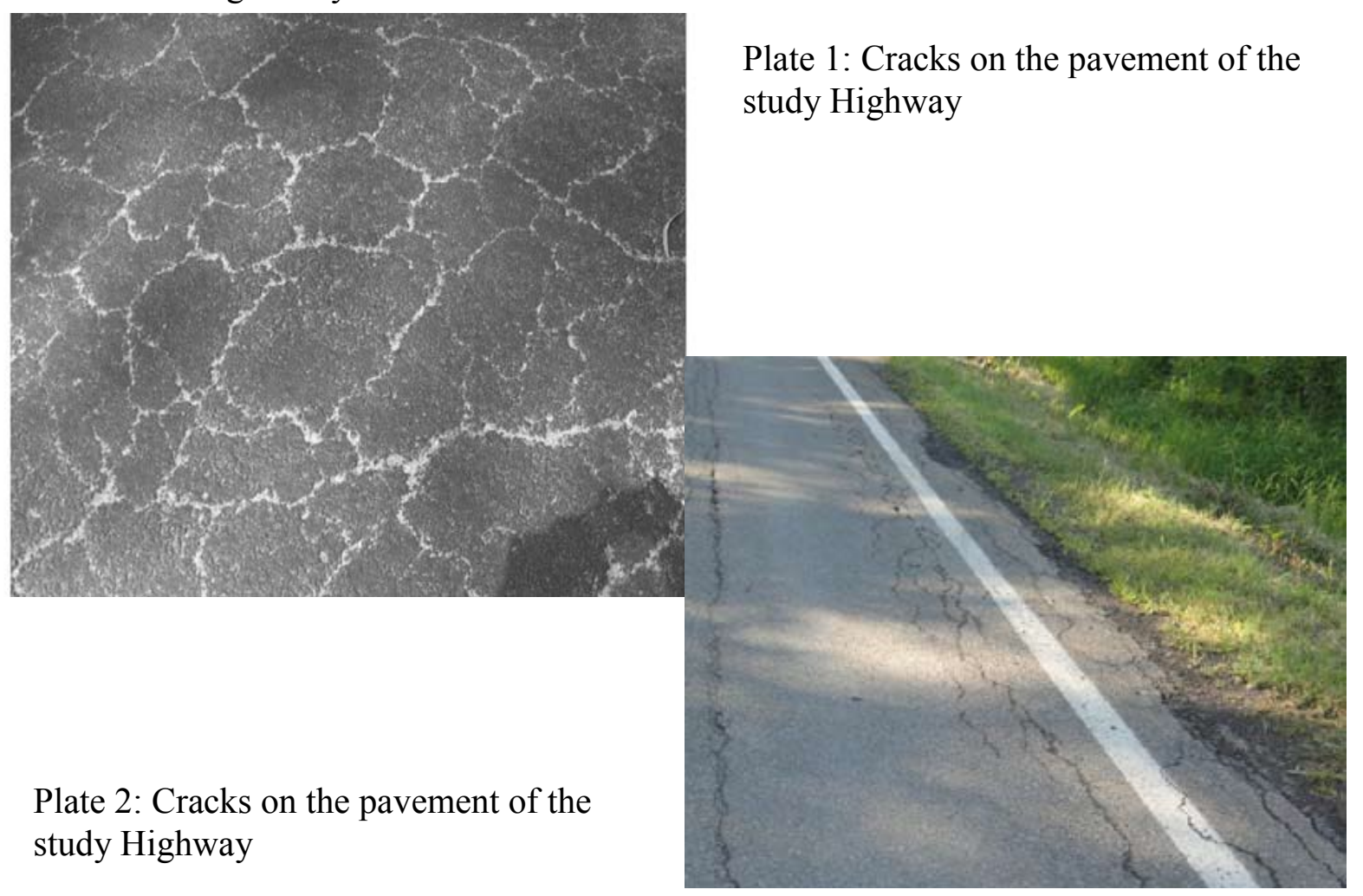

\section{LOCATION OF THE STUDY AREA}

The study area Ago-Iwoye - Ilishan road, is situated in the south-western part of Nigeria within latitudes $06^{0} 53^{\prime} 00^{\prime}$ '- $06^{0} 57^{\prime} 00^{\prime}$ and longitudes $3^{0} 44^{\prime} 00^{\prime}-3^{0} 56^{\prime} 00^{\prime}$ (Fig. 1.0). The road traverses Irolu, Ijesha-Ijebu, Oladele, Ajegunle settlements with other small villages. Akanni, (1991) stated that Ago -Iwoye - Ilishan road can be specifically placed in the humid tropical region. The rainy season ranges from mid-March to early November with double maxima of rainfall whose peaks occur in June and September while the dry season lasts from November to early March with the month of December and January relatively dry. The mean monthly rainfall varies from less than $50 \mathrm{~mm}$ in January to over $200 \mathrm{~mm}$ in June and July. A relatively lower amount of about $140 \mathrm{~mm}$ in August is due to the little dry season or August break, which is the normal form of climatic condition throughout Nigeria. The vegetation of the area is characterized by the rain forest type influenced by human activities such as construction of roads and houses, farming etc. River Ome is the main river that forms the drainage. The river flows through a N-S direction, parallel or sub-parallel to the strike of the rock with dendritic drainage pattern.

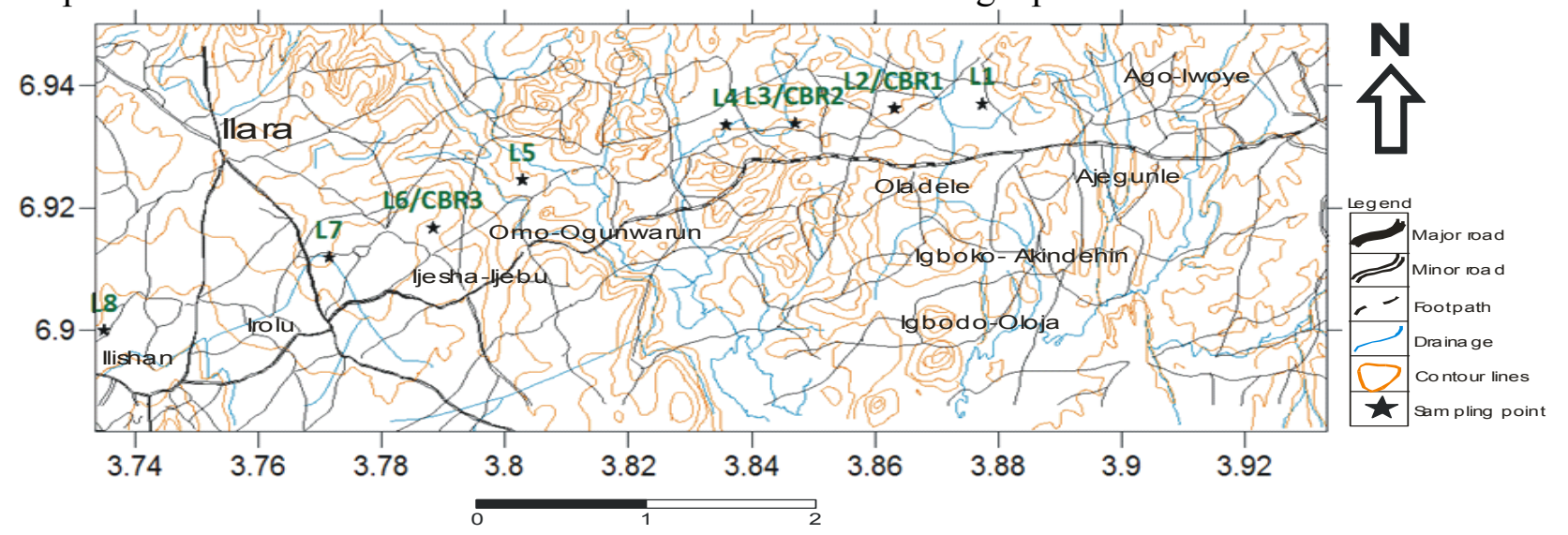

Figure 1.0: Location map of the study area 


\section{GEOLOGY OF THE STUDY AREA}

The half of the study area falls within the Basement Complex of southwestern Nigeria and it is predominantly underlain by gneisses of various grades and suites. These rocks are porphyroblastic gneisses, Biotite gneisses, granite gneisses and banded gneisses. There is an occurrence of a massive intrusive body of quartz schist at the southern part of the area. Some other part of the study area falls within the Sedimentary terrain which is Ise formation of Abeokuta group as shown in Figure 2.

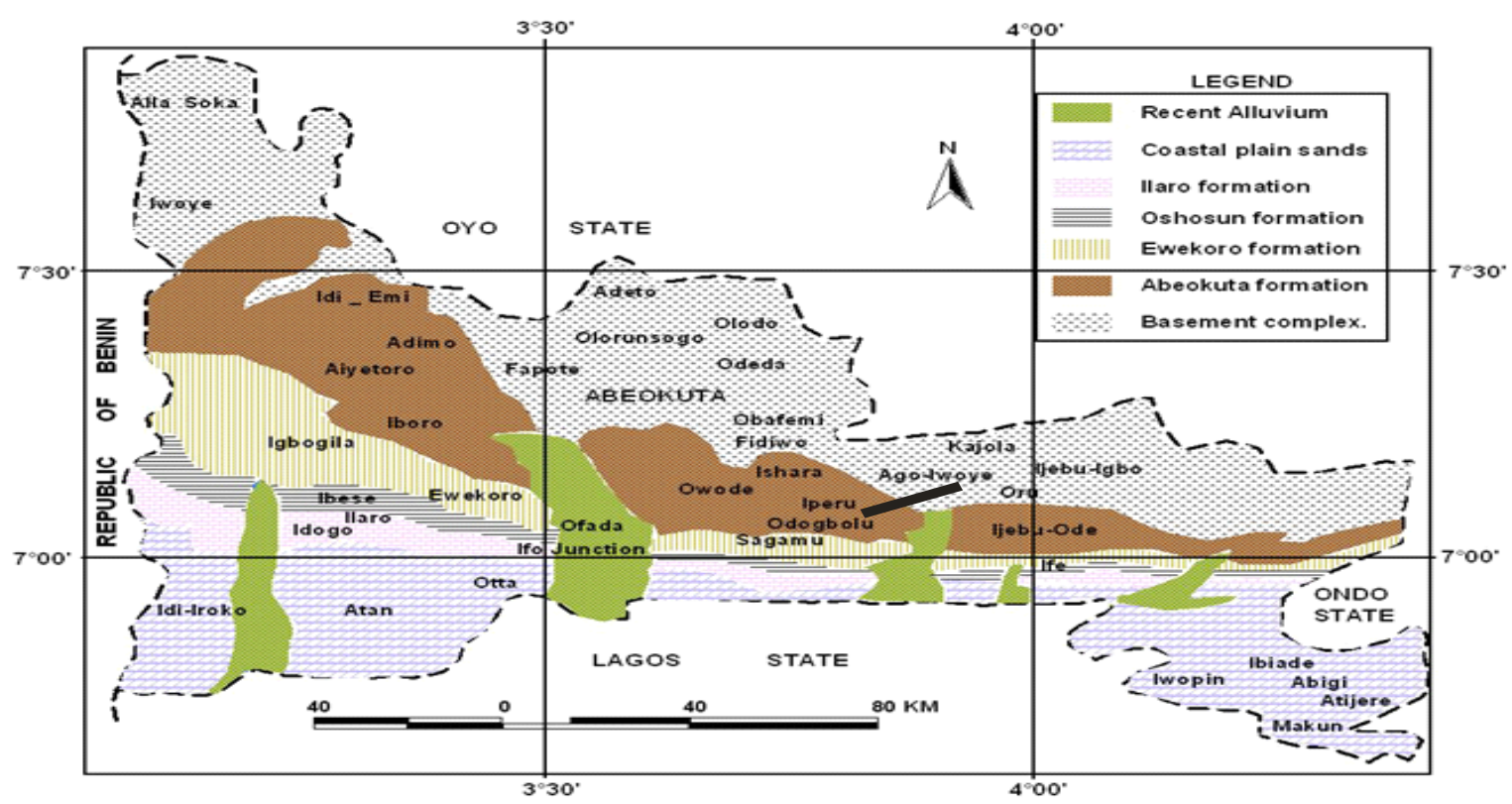

Figure 2.0: Geological map of Ogun State showing different areas (Adopted by Olurin et al., 2012).

\section{MATERIALS AND METHODS}

Eleven (11) samples were collected at eight (8) different locations with the aid of hand auger and digging tools for trial pits. The soil samples were air-dried before being subjected to the laboratory tests such as the grain size analysis, moisture content, consistency limits, compaction test and the California Bearing Ratio (CBR). The results of the grain size analysis were presented as grain size distribution curves, that is, plotting of percentage of soil passing against the grain size on a semi-log graph. Typical grain size distribution curves are shown at Fig. $3(\mathrm{a} \& b)$.

The soils were classified by using the American Association of State Highway and Transport Official (AASHTO) and USGS methods. The AASHTO classification identified two major soil types along the road route which are A -6 and A -7 category which rated the soils fair to poor subgrade materials.

The USGS classification method identifies silty sand (SM) and clayey sand (SC) soil types along the road route. The laboratory tests were conducted accordance with the procedure specified by the American Society for Testing and Materials (ASTM 1289, 1979) and the British Standard Institute (BSI 1377, 1990). 


\section{RESULTS AND DISCUSSION}

The results of the laboratory analysis of the soil samples were presented as distribution curves and summary of geotechnical properties of the subgrade soils. A typical distribution curve is as shown in figure $3.0(\mathrm{a} \& b)$.

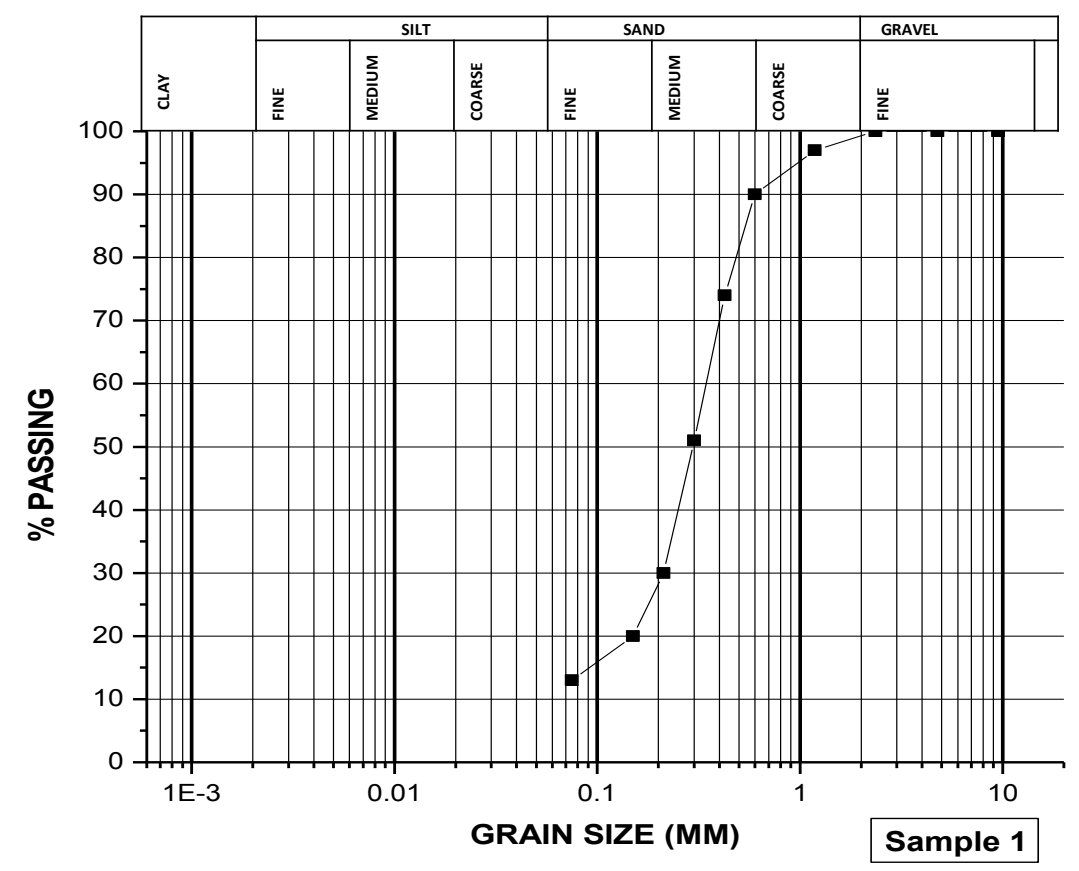

Figure 3a. Grain size distribution curve for Sample 1

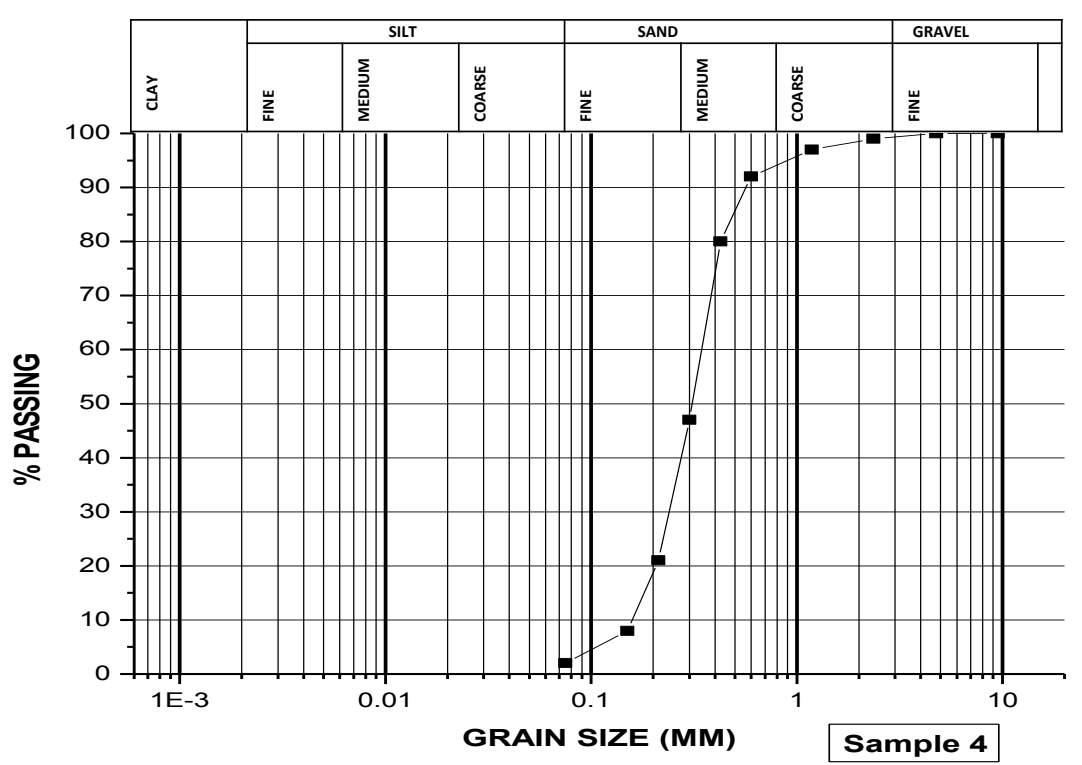

Figure 3b. Grain size distribution curve for Sample 4

Figure $3 \mathrm{a}$ shows the grain size distribution curve for sample 1 where the percentage of soil passing is plotted against the grain size $(\mathrm{mm})$. This shows that percentage of coarse soil is $86 \%$, while that of fine soil is $14 \%$. For figure $3 \mathrm{~b}$, the percentage of coarse soil is $98 \%$ and fine soil is $2 \%$. Table 1 shows the summary of the geotechnical properties of the subgrade soils. The values represent the average for three replicate of each sample tested. 
The geotechnical properties of the subgrade soils along the highway route revealed that the liquid limit values ranges from $13.9 \%$ to $40.0 \%$ and plasticity index ranges from $10.6 \%$ to $15.9 \%$ against the FMWH, 1997 specify value of $40 \%$ maximum and 10\% minimum for liquid limit and plasticity index respectively.

The soaked CBR values of the subgrade materials is between $67 \%$ and $75 \%$ compared with $30 \%$ minimum specified by FMWH, 1997. The laboratory maximum dry densities are between $1.47 \mathrm{Mg} / \mathrm{m}^{3}$ and $1.68 \mathrm{Mg} / \mathrm{m}^{3}$ while optimum moisture content ranges from $18.5 \%$ to $26.7 \%$. These values are still within the acceptable values of FMWH, 1997 for good to fair subgrade materials. Averagely $75 \%$ of the samples satisfy the requirement that the LL and PI of sub-grade should not be more than 35 and 12\% respectively (FMWH,1997).

\section{CONCLUSION}

The results of the subgrade soils investigation along Ago-Iwoye - Ilisian road revealed that the road pavement structures are underlain by are $A-6$ and $A-7$ category of soils, which rated the soils fair to poor subgrade materials. Averagely $75 \%$ of the samples collected satisfy the requirement that the LL and PI of sub-grade should not be more than 35 and $12 \%$ respectively. The soaked CBR values of the subgrade materials is between $67 \%$ and $75 \%$. The CBR values are relatively high, which is an indication that the subgrade soils are good to fair for pavement structures.

The comparison all the results with the Nigeria specification (Federal Ministry of Works and Housing general guidelines) for the subgrade materials along the Ago-Iwoye- Ilisian road show that the materials underlain the pavement do satisfy the Nigeria standard. Therefore, the perennial failure frequently experience along the road route is not significantly influenced by subgrade materials. Hence, influence of other factors such as poor drainage courses, level of groundwater table, variation of geologic materials along the road route and poor construction materials should be thoroughly addressed before embarking on future rehabilitation of the highway. 


\begin{tabular}{|c|c|c|c|c|c|c|c|c|c|c|c|c|c|c|}
\hline \multirow{11}{*}{ 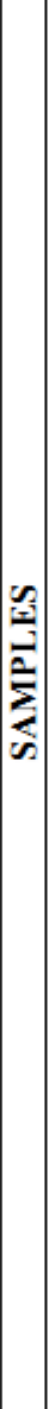 } & 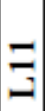 & In & $\approx$ & $\vec{m}$ & $\overline{\mathrm{d}}$ & $\ddot{\infty}$ & $\stackrel{\infty}{\infty}$ & $?$ & نٌ & $\frac{\infty}{\operatorname{s}}$ & ï & 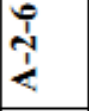 & $\sum_{\infty}$ & $\stackrel{\oplus}{\tilde{\omega}}$ \\
\hline & $\Xi$ & $\underline{\infty}$ & $\boldsymbol{\infty}$ & $?$ & $\frac{9}{F}$ & $\stackrel{2}{\stackrel{2}{N}}$ & 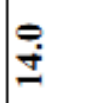 & 疋 & 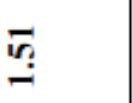 & 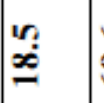 & 迥 & $\grave{z}$ & $\underset{\mathscr{S}}{U}$ & 离 \\
\hline & $\theta$ & $\vec{\sim}$ & $F$ & $\dddot{q}$ & $\stackrel{\vec{\ominus}}{F}$ & $\vec{x}$ & $\exists$ & 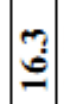 & 管 & $\overrightarrow{\stackrel{\sim}{\oplus}}$ & $\frac{\partial}{\pi}$ & 紊 & $\sum_{\infty}$ & 啇 \\
\hline & $\infty$ & + & 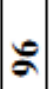 & $\stackrel{\sim}{2}$ & : & 2 & $\underline{\mathrm{z}}$ & $\stackrel{\infty}{r}$ & , & ' & ' & $\stackrel{0}{<}$ & $\underset{\sim}{U}$ & $\stackrel{\oplus}{\mathscr{\omega}}$ \\
\hline & 3 & $N$ & $\approx$ & 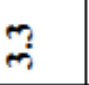 & 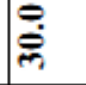 & $\exists$ & 全 & $\mid$ & , & ' & ' & $\stackrel{\varphi}{<}$ & $\bigcup_{\mathscr{N}}$ & 实 \\
\hline & $\stackrel{0}{.}$ & $\equiv$ & $\Xi$ & Na & 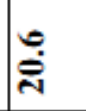 & $\begin{array}{l}\infty \\
\infty \\
\infty\end{array}$ & $\stackrel{\infty}{=}$ & $\mid \begin{array}{l}\infty \\
\dot{\omega}\end{array}$ & ' & I & ' & 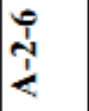 & $\bigcup_{\infty}$ & 离 \\
\hline & 13 & + & 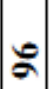 & $\stackrel{N}{\underset{T}{*}}$ & $\ddot{\infty}$ & $\vec{\infty}$ & $\stackrel{\varphi}{\stackrel{\Xi}{\Xi}}$ & $\underset{7}{2}$ & , & I & I & 市 & $\sum_{\infty}$ & 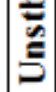 \\
\hline & $\stackrel{ \pm}{\Xi}$ & $N$ & $\approx$ & $\stackrel{N}{r}$ & $\hat{\vec{m}}$ & ' & $\vec{\theta}$ & רֶ) & , & ' & I & $\underset{1}{\alpha}$ & $\bigcup_{\mathscr{N}}$ & 离 \\
\hline & 3 & $\underline{2}$ & 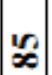 & $\stackrel{N}{\triangleq}$ & $\stackrel{n}{2}$ & $\stackrel{2}{\underline{I}}$ & $\bar{z}$ & $\overline{\boldsymbol{x}}$ & , & I & , & $\stackrel{i}{<}$ & $\bigcup_{\mathscr{N}}$ & $\underline{\underline{m}}$ \\
\hline & $\begin{array}{c}\mathbf{N} \\
\mathbf{3}\end{array}$ & $\underline{-}$ & $\boldsymbol{\infty}$ & $\stackrel{2}{2}$ & ֶֶ. & స̂ं & 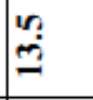 & $\stackrel{\Omega}{\sim}$ & ' & ' & ' & $\stackrel{1}{<}$ & U্র & $\stackrel{\bar{v}}{g}$ \\
\hline & $=$ & \pm & 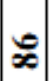 & $\vec{m}$ & 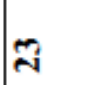 & $\stackrel{\square}{\Xi}$ & $\stackrel{\text { }}{=}$ & $\begin{array}{l}0 \\
\infty\end{array}$ & 1 & ' & , & $\underset{1}{0}$ & $\sum_{\infty}$ & $\stackrel{\bar{v}}{\mathrm{~s}}$ \\
\hline 敨 & & 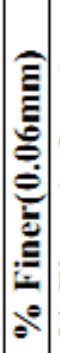 & 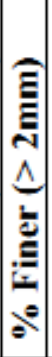 & 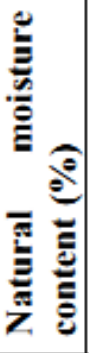 & 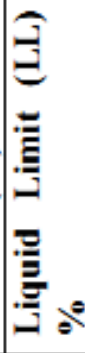 & 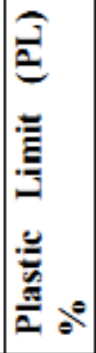 & 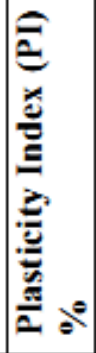 & 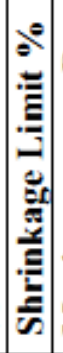 & 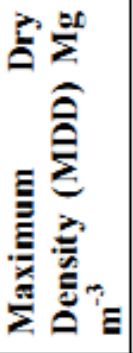 & 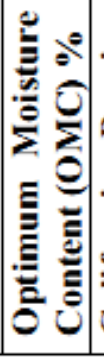 & 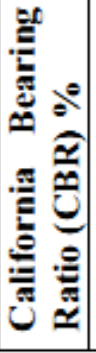 & 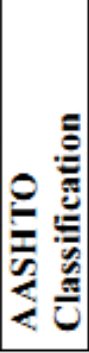 & 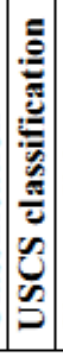 & 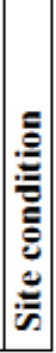 \\
\hline
\end{tabular}

\section{References}

[1] AASHTO (1962): Road Test Report 5 (PavementResearch), Highway Research Board, Special Report 6IE Washington D.C.

[2] Akanni, C.O. (1991). Relief, drainage, soil and climate of Ogun. In: Ogun State in maps. Edited by Onakomaiya, S.O; Oyesiku, O.O and Jegede, F.J. Published by Rex Charles Publications, 6 -20p.

[3] Bayewu, O.O, Oloruntola, M. O., Mosuro, G. O. and Adeniyi S. A. (2012): Petrographic and geotechnical properties of Lateritic Soils developed over different parent rocks in AgoIwoye area, Southwestern Nigeria. Int. Journal of Applied Sciences and Engineering Research, Vol. 1, Issue 4. 
[4] Federal Ministry of Works and Housing (FMWH)1972. Highway Manual Part 1 Road Design. Federal Ministry of Works and Housing, Lagos.

[5] Jegede, G. (2004): Highway Pavement Failure Induced by Poor Geotechnical Properties along a section of F209 Okitipupa-Igbokoda Highway Southwestern, Nigeria. Ife J. Sci., 6(1): 41-44. Journal of Soil Science and Environmental Management Vol. 3(5), pp. 110-117.

[6] Mcghee KH (2010). Development and Implementation of Pavement Condition Indices. J. Sci. Res., 1(2): 10-18.

[7] Olurin O. T., Badmus B.S, Akinyemi O.D, Olowofela J.A, Ozebo V.C \& Ganiyu S.A (2012): Analysis of Physical Parameters of Limestone Deposits in Ewekoro Formation, Southwestern Nigeria, Journal of Earth Science Research; Vol. 1, No. 2;117-121.

[8] Sarsam, S.I. (2010). Visual Evaluation of Pavement Surface Condition Using an Expert System. Indian J. Highways, 2(1): 20-26.

[9] Talukder, M.J. (2009). Evaluation of Existing Pavement of Sylhet-Sunamganj Road by Dynamic Cone Penetrometer. The institution of Engineers, Bangladesh. Penetrometer. J. Civil Eng., 35(1): 51-59.

[10] Woods, W.R., Adcox, J.W. (2006): A general characterization of pavement system failures with emphasis on a method for selecting repair process. J. Construct. Transport., 14(2): 2634. 